\title{
POLITICAL RHETORIC AND PUBLICITY IN THE DIGITAL AGE
}

\section{ANNELI BARAN}

The Anti-Counterfeiting Trade Agreement began attracting wider attention in Estonia in January and February 2012. News offurious speeches and demonstrations all over the world also reached Estonia. Appeals to people to come out and express their opinion were made on social networks, where various communities were created. However, the attributes used in the demonstrations were mostly inspired by well-known Estonian politicians' speeches. Politicians have caught on to the influence of the web and they use various opportunities to broadcast their opinions and conduct political lobbying. Keywords: internet, social media, journalism, politicians, figurative language
VEstoniji je trgovinski sporazum za boj proti ponarejanju pritegnil većjo pozornost v januarju in februarju 2012. Prav tako so dosegle Estonijo novice o demonstracijah po vsem svetu. Socialna omrezja, kjer so bile oblikovane različne skupnosti, so pozivala ljudi, naj se zberejo in izrazijo svoje mnenje. Vendar so se protestniki pri rabi in repertoarju stališč večinoma zgledovali znanih estonskih politikih, $k i$ so uporabili splet, da bi tudi na ta način labko posredovali svoja stališća in politično lobirali.

Ključne besede: internet, socialni mediji, novinarstvo, politiki, figurativni jezik

\section{INTRODUCTION}

During the last ten years, much has changed in society, and these abrupt social changes are logically reflected in culture and language. The mindset and language of people today is greatly influenced by mass communication, especially via the World Wide Web.

This article ${ }^{1}$ is based on two events that received wide coverage in the Estonian media. Both took place in January and February 2012, but are still in people's minds and on their tongues.

Incidentally, both cases grew out of the utterances of well-known politicians-the Estonian prime minister and the previous prime minister, who was the defense minister at that time-on topics very important for young people; namely, everything internetrelated. The fact that Estonian youth are, according to various studies, one of the most active internet-using groups is one that cannot be ignored. As a folklore specialist, every year I have to give more credence to the fact that the internet is a major influence on the folklore and language of schoolchildren. ${ }^{2}$

1 This study was supported by the Estonian Ministry of Education and Research (IUT 22-5, EKKM14385) and by the European Union through the European Regional Development Fund (Center of Excellence in Estonian Studies).

2 This was also clearly demonstrated by the Estonian school folklore competition in 2007, organized by the Folklore Department at the Estonian Literary Museum. 
Today, it is common to speak about the phenomenon called internet communication or internet language, not to mention multifarious phenomena that exist only in the internet environment. This sentiment is backed up by statistical data. In 2012, two-thirds of people in the EU used the internet every day or at least once a week (so-called regular internet users, age 16 to 74). The highest concentration of regular internet users was found in Denmark, Ireland, Luxembourg, Finland, and Sweden, and the lowest in Bulgaria, Hungary, Lithuania, Romania, and Italy. Estonia was slightly above the European average ( $79 \%$ compared to 75\%), and, in the 16-24 and 25-54 age groups, Estonia had more internet users than the $\mathrm{EU}$ in general (65\% compared to $58 \%$, and $43 \%$ compared to $36 \%$, respectively). ${ }^{3}$

It is remarkable how the internet or online technologies in general reinforce people's attitudes and behavior. At the same time, as some researchers such as Zizi Papacharissi have noted, there is a complex relationship between technology and democracy. Papacharissi points out that this kind of relationship is shaped by the balance between the public and the private, stressing that "the unique affordances of newer media technologies enable particular civic habits" (2011: 12).

Politicians have also caught on to the influence of the web and use various opportunities to disseminate their opinions and conduct political lobbying. Characteristically, people pick up utterances that are much more expressive than those published for the public media, and thus give the expressions new life. Like blogs, Facebook updates, Twitter tweets, and so on, online media can turn something someone has said into a news item that can generate lively discussion, which may quite often even escalate and transcend virtual world borders. ${ }^{4}$

The authorities are naturally aware of the relation between social media and regular media, which makes one wonder why they try to wriggle out of a problem by claiming that a statement was only a spontaneous reaction and need not be amplified by the media (e.g., the so-called dispute between Estonian President Toomas Henrik Ilves and Nobel Prize-winning economist Paul Krugman about the economic success of Estonia, initiated by Ilves' very sharp criticism of the other on a Twitter account). There are also some politicians that do not restrict their unique wording habits to the blogosphere or social networks, but also use them when communicating with journalists. As an example, I would like to present the curious comparisons made by the minister of finance of Estonia, ${ }^{5}$ in which he used expressive wording in discussions concerning EU aid packages. First I present the quote from the interview, in which a journalist's question required the minister's answer.

3 Eurostat 2012. Statistics in Focus, http://ec.europa.eu/eurostat/documents/3433488/5585460/KS-SF12-050-EN.PDF, accessed August 30th, 2016.

4 It is quite obvious the breakthrough occurred in 2011, when people around the world decided to come out onto the streets (e.g., the Arab Spring, the Occupy Wall Street movement, and demonstrations in Russia). There were various reasons behind these large-scale protests, but they have one factor in common: media awareness. See also Shifman (2013).

5 Regarding the relation between figurativity and spontaneity in speeches by Estonian politicians, see Baran (2011). 
Estonia has bet on adhering to the rules. Seeing how others have not made similar contributions, is it time to change the strategy? -

They [all] contribute more and more. The countries are tense, watching each other. The neighborhood watch is growing stronger. One could not say that there is much room for irresponsibility in Europe. The problem lies rather in the inability to stay above public opinion. That is the problem. Public opinion does not support cuts or helping. I would define it as porn if the demand were made that every last person should understand everything and every last person should be queried. . . (Jürgen Ligi: one needs to stay above public opinion in order to push necessary decisions through). ${ }^{6}$

The rest of the media hurried to immediately exploit such an expressive phrase. Here is only one headline from a tabloid: Jürgen Ligi: See on porno, kui nóuda, et iga inimene köigest aru saaks! 'Jürgen Ligi: It Would Be Porn If Everyone Understood Everything!'”

However, the clear-cut positions of politicians using expressive language become quotes or catchphrases in the media even if they are not made through online channels or addressed directly to the media. However, in my next examples, the public speeches did concern the internet.

\section{ANALYSIS AND DISCUSSION:ACTA AND ESTONIAN PRIME MINISTER ANSIP}

The Anti-Counterfeiting Trade Agreement (ACTA) ${ }^{8}$ started drawing wider attention in Estonia in January and February 2012. News of furious speeches and demonstrations during meetings in other countries had, of course, reached the country. However, people became active in Estonia only after a very emotional parliamentary speech delivered by the prime minister.

Andrus Ansip ${ }^{9}$ was unable to disguise his heartfelt anger at journalists that dared to frighten people with the ACTA topic. The media, however, naturally turned the prime minister's speech into a news item, quoting him punctiliously.

6 See http://majandus24.postimees.ee/v2/904868/juergen-ligi-vajalike-otsuste-laebisurumiseks-tulebavalikust-arvamusest-uele-olla (accessed August 30th, 2016).

7 See http://www.ohtuleht.ee/484452 (accessed August 30th, 2016).

8 More detailed information can be found at http://www.stopacta.info/\#Procedure (accessed August 30th, 2016).

9 As a remarkable fact, Andrus Ansip had the longest career as a prime minister in Europe: nine years. Paradoxically, Ansip, who justified legislation such as ACTA, became the EU's digital single market commissioner some years ago. 
The news item was characteristically published by the news media with a link to the video of the parliamentary discussion. Here one can see a new approach by the modern media - they are trying to engage the reader primarily through their emotions, not only cognitively. Here, I would like to expand on the conclusion of Papacharissi and Maria de Fatima Oliveira (2012), who ascribe such a quality primarily to social media news platforms such as Twitter, but this quality is characteristic of all media platforms.

The first quote excerpted here includes comparisons with other countries, including the United States and Sweden, and with such things as swine flu or a goat, whereas the second quote includes expressions that have now developed an independent life.

Let us imagine for a moment that the Swedes have also signed this agreement. Can you imagine that the prime minister of Sweden or the president of the United States would have signed an agreement with the intention of one day turning off the internet, as can be read in our media, especially [daily tabloid] Óbtuleht, right now? In Sweden, freedom of speech is honored even more than it is honored in Estonia. It is absolutely ruled out that the government of Sweden would do something that would restrict people's access to information, would somehow restrict freedom of speech. I do not understand the hysterics in Estonia! This reminds me of swine flu. For a long time we stood against the purchase of a very expensive vaccine but finally could not resist any longer-twenty million kroons went down the drain. As if a goat had swished its tail! Could not resist the hysterics! It seems to me that now the same is going to happen.

"Allow me to quote Óhtuleht. February 6, 2012: 'ACTA is a treaty engineered in the developed countries in secret from the people, forcing internet service providers to supervise everything done online and to punish any kind of copyright infringement with a hefty fine or imprisonment without trial.' Look what we are heading for! 'Bans cheaper analogue drugs with a similar effect and patent the seeds of plants and crops, which can then no longer be raised by anybody on their fields.' Friends! Agriculture is now totally done for! Laar [ex-prime minister and current minister of defense, Mart Laar] tried and didn't manage, but ACTA will do it! You know, somebody who claims something like this, that person has eaten seeds and not the seeds we sow in our fields. Usually if people have such suspicions, wearing tinfoil in one's hat sometimes helps. Some think a bubble bath could help, too. I do not know what could help in this specific case, but people should seek help from somewhere!" said the prime minister. (Ansip: ACTA is a supremely right thing $)^{10}$

10 See http://majandus24.postimees.ee/v2/732312/ansip-acta-on-uelimalt-oige-asi (accessed August 30th, 2016). 
The verbal attack was full of expressive and juicy language usage. Mediated by journalism, primarily represented in Estonia by the daily newspapers Postimees and SL Óhtuleht, and the online news portal Delfi (which also has a subsection called Rahva hääl 'Vox populi' because it aggregates not only news from other media sources but also publishes original pieces by ordinary people), oral speech acquired expressions about suspicious seeds and tinfoil hats and bubble baths that found their way into headlines.

- Ansip using irony: agriculture is now done for! Laar tried and didn't manage, but ACTA will do it! ${ }^{11}$

- Ansip: the anti-ACTA have eaten seeds and should seek help! ${ }^{12}$

All of these articles were illustrated with a YouTube link to the video of the prime minister's speech. ${ }^{13}$

The speech led to (pointedly ultra-negative) discussions, not only in the comment sections of websites and news portals (e.g., the tabloid SL Óhtuleht with 155 comments, Delfi with 318 comments) but also in numerous opinion articles and, naturally, social media.

Commenters often lose sight of the gist of the matter and tend to only swear. ${ }^{14}$ To clarify, Estonian media publications traditionally have anonymous comment sections. Only individual publications have personalized them in recent years. Anonymity allows for a more liberal style of expression, which in turn has caused fierce debates on the topic of restricting such behavior. At this point, I present some typical examples related to the topic of ACTA: ${ }^{15}$

- I don't know, what's wrong with this Ansip, started to scream like a pig stuck in a fence. This man definitely needs a check-up. I don't want such a hysterical prime minister, I'm embarrassed. (ups, February 9th, 2012)

- Estonia as a country worth living in is also done for-Ansip and his gang organized this like a snap and, to be really sure, fires the last shot with ACTA (azza, February 9th, 2012)

- Pisses from above on his people and calls them stupid, keep doing that, anus! Soon you will receive your due, you damn bastard! (asd, February 9th, 2012)

- It seems this communist dummy has finally lost his last marble. (propeller, February 9th, 2012)

- Hasn't anybody given him a punch?? He does not understand life ... a man just loses touch if he sits so long on boundless benefits!!! (parmordu, February 9th, 2012)

As in other countries, Estonia also held demonstrations in several towns in protest of ACTA, as part of the global NO to ACTA movement, but the attributes used were inspired

11 See http://www.delfi.ee/news/paevauudised/eesti/ansip-iroonitseb-pollumajandusega-on-nuud-labilaar-uritas-ei-saanud-hakkama-acta-teeb-selle-ara.d?id=63894023 (accessed August 30th, 2016).

12 See http://www.ohtuleht.ee/463716 (accessed August 30th, 2016).

13 See http://www.youtube.com/watch?v=E9AhCd-ygkg (accessed August 30th, 2016).

14 On the flaming aspect and verbal aggressiveness of Estonian news portals, see Laineste (2012).

15 All examples of comments date from the aforementioned article in the news portal Delfi. 
foremost by the prime minister's speech ${ }^{16}$ (see two screenshots from YouTube on the page 33). Paradoxically, as political semioticians have observed, those debates over ACTA brought together contradictory value systems; one the one hand, protesters were talking about freedom of speech, but on the other they clearly presented a racist self-model, accusing politicians not only of censorship, but also of being a part of a neoliberal world (Madisson 2016: 35).

Appeals to people to come out and express their opinion were made on social networks, where various communities were created (e.g., Fooliummütsid pähe/seemned kaasa 'Tinfoil hats on / seeds with you', ${ }^{17}$ as well as in the aforementioned comments on internet articles.

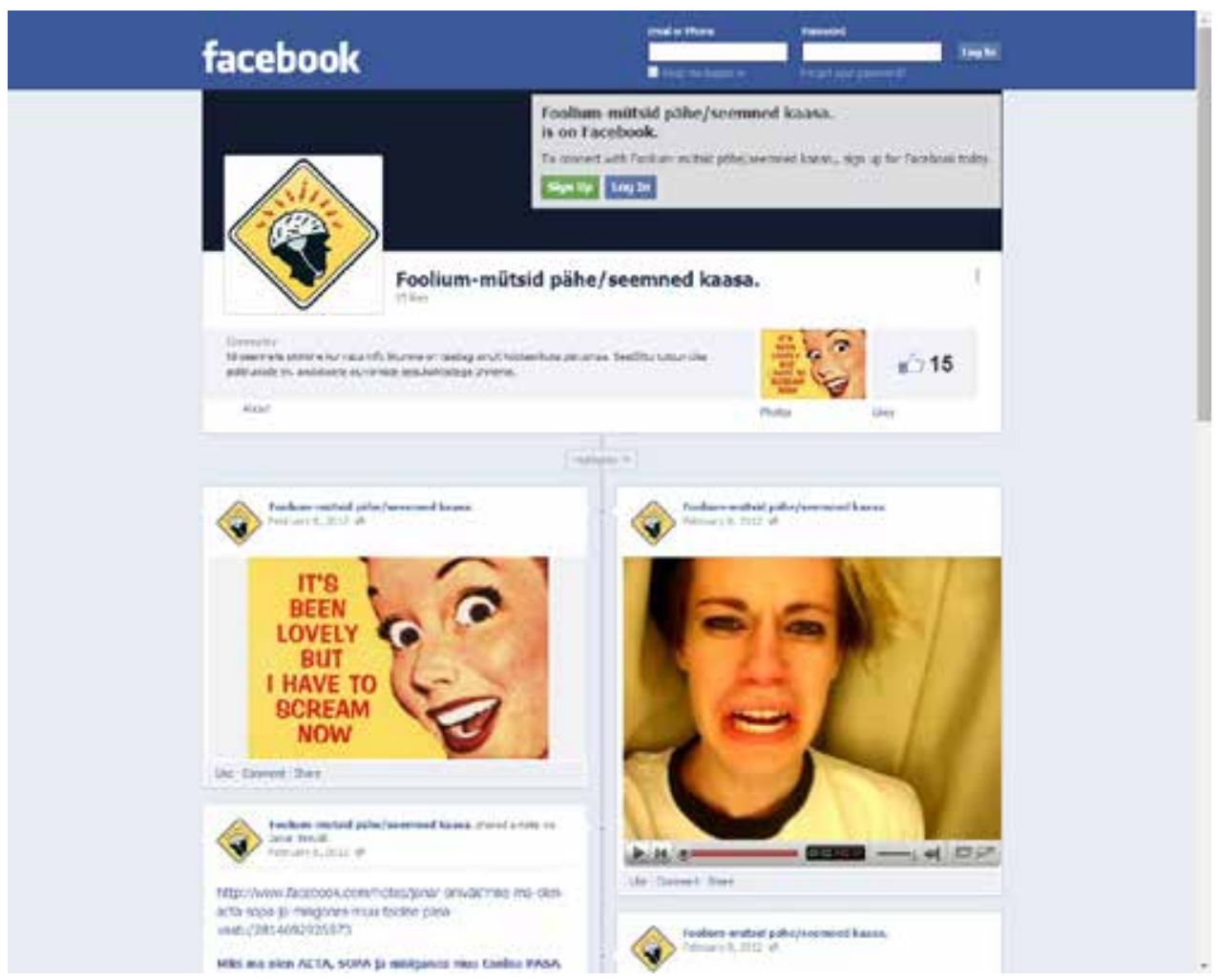

Figure 3: Facebook site created as a response to the Estonian prime minister's talk.

The internet retains both the speech by the prime minister as well as a flood of parodies. Here I present here the most expressive of them. Photoshopped mock pictures or manipulated photos, including demotivationals ${ }^{18}$ (i.e., photo and text combinations with a particular structure) abounded online. The first two are based on election posters.

16 See http://www.youtube.com/watch?v=-7TsNvnfPi4\&feature=related (accessed August 30th, 2016).

17 See http://www.facebook.com/pages/Foolium-m\%C3\%BCtsid-p\%C3\%A4heseemnedkaasa/321118761271829 (accessed August 30th, 2016).

18 For a more detailed study, see Shifman (2013). On Estonian studies on this topic, see Baran (2012). 

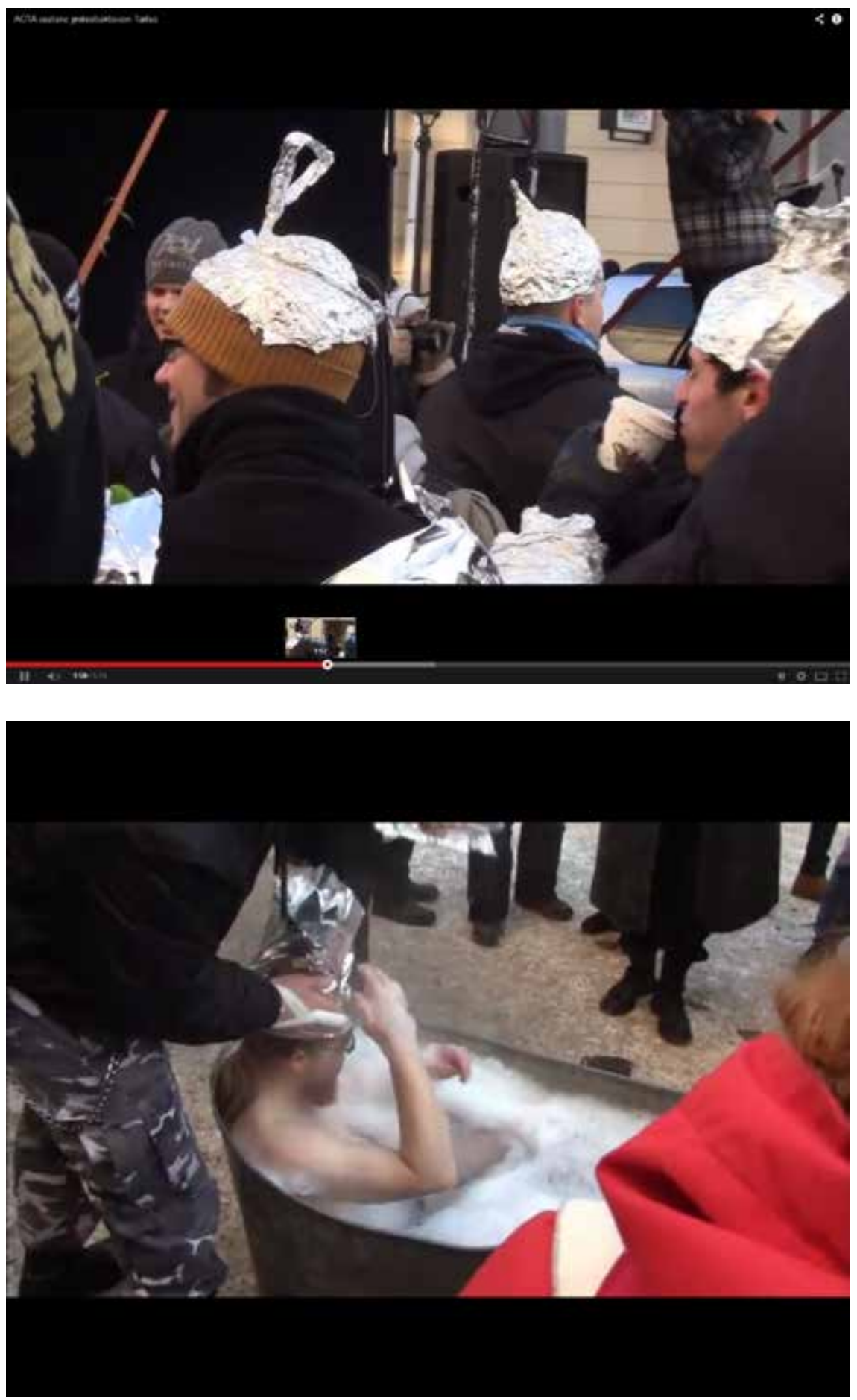

Figure 1 and 2: ACTA protesters, wearing tinfoil hats, or taking a bubble bath, at Tartu Town Hall Square. 

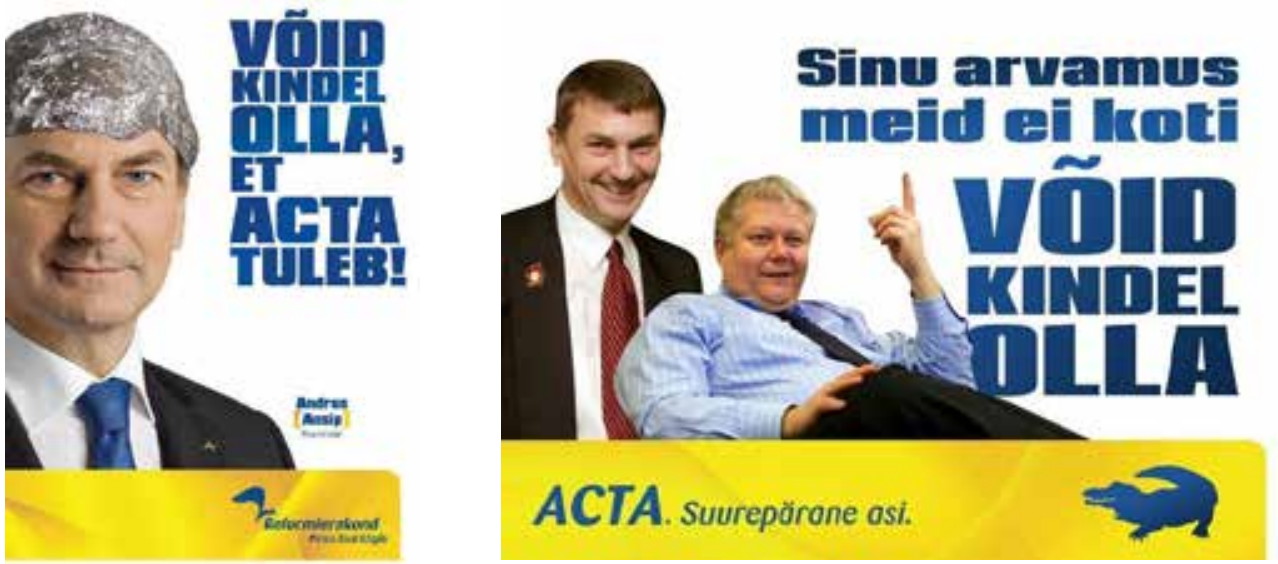

Figure 4. Void kindel olla, et Acta tuleb! 'You can be certain that ACTA will come!'

Figure 5. Sinu arvamus meid ei koti, võid kindel olla. Acta. Suurepärane asi. 'We don't care about your opinion, you can be certain of that. ACTA, an excellent thing'

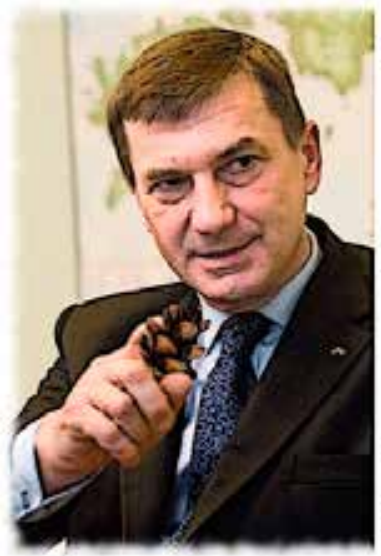

\section{SINA,MU SÕBER}

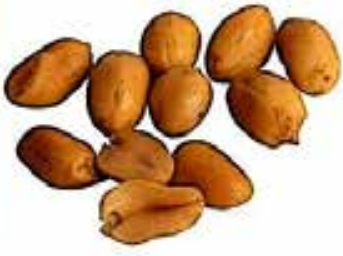

OLED KAHTLASEID SEEMNEID SÖÖNUD

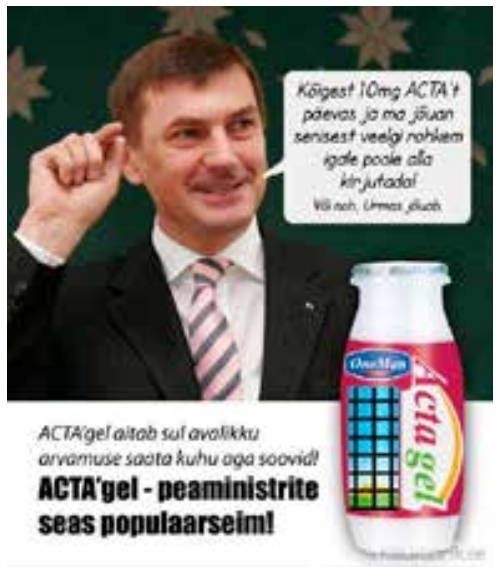

Figure 6. Sina, mu sōber, oled kahtlaseid seemneid söönud 'You, my friend, have eaten suspicious seeds' Figure 7. Actagel aitab sul avaliku arvamuse saata kuhu aga soovid! Actagel-peaministrite seas populaarseim! 'ACTAgel helps you send public opinion where you want! ACTAgel, popular among prime ministers!'

In addition, parodying clips (or memetic videos) on YouTube titled Hitler reageerib Acta-vastasele protestile 'Hitler reacts to anti-ACTA protest', ${ }^{19}$ and an online game called Ansipi seemnemääraja 'Ansip's Guide to Seeds' appeared (with the slogan 'Help Andrus eat seeds!'). ${ }^{20}$

19 See http://www.youtube.com/watch?v=D8tZGj8ZILs\&feature=related (accessed August 30th, 2016). On the distinction between viral versus memetic videos, see Shifman (2012).

20 See http://aplefly.com/ansipi-seemnemaaraja (accessed August 30th, 2016) 


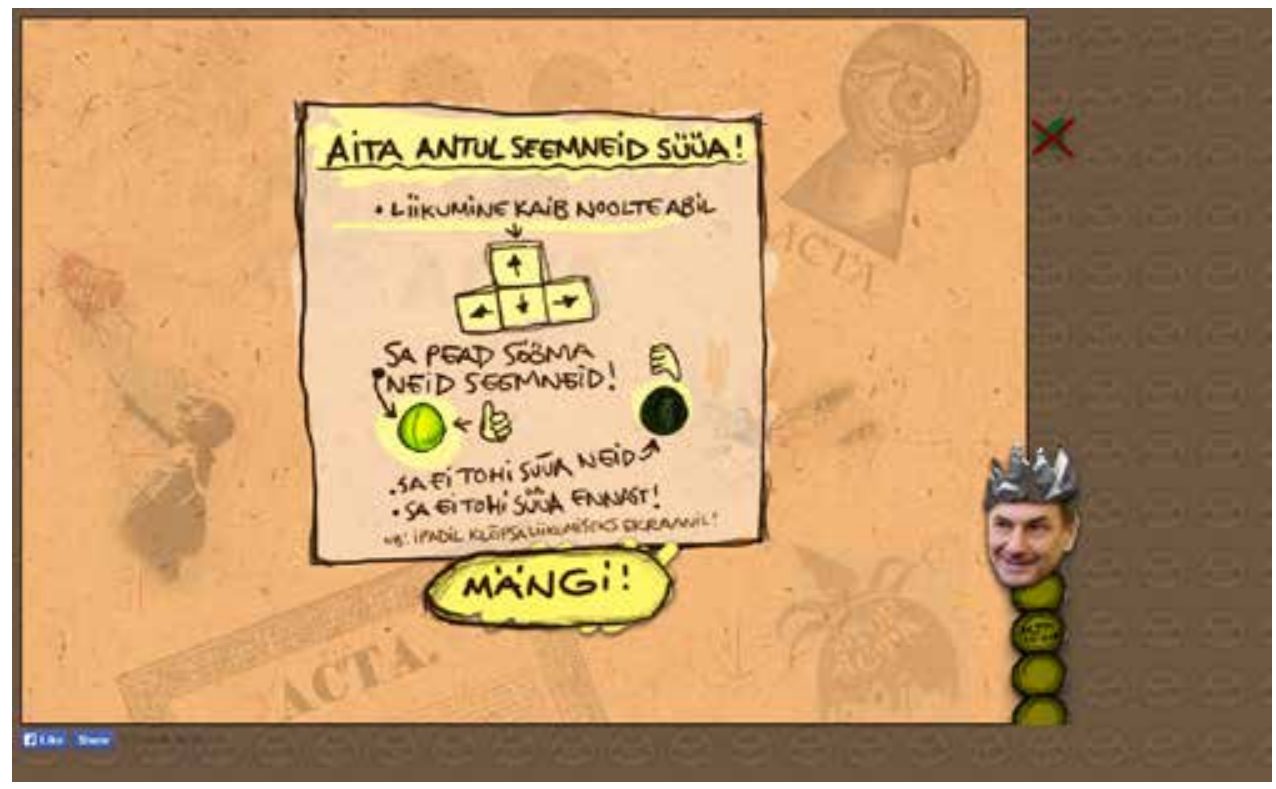

Figure 8. Online game inspired by the prime minister.

Returning to the imagery used in the original speech, the prime minister's phrase about eating seeds as referring to narcotic substances and tinfoil hats as a means of defense are still alive in language usage. For example, a Google search finds about 5,880 references ${ }^{21}$ to tinfoil hats, most of them imperative:

- Fooliummüts pähe ja kuss!'Put a tinfoil hat on and keep quiet!'

- Fooliummütsid pähe ja seemet jagama! 'Let's wear tinfoil hats and distribute the seed'! Such catchphrases are not political statements on so-called anti-placards ${ }^{22}$ so much as they are expressions of everyday language based on parody and humor.

These examples originated at the very beginning of 2012. However, the ACTA topic was important for people all year long. I present only some opinions from one forum, ${ }^{23}$ where people were discussing transaction taxes, as an illustration:

- In the case of ACTA, it was the same: it "has been dealt" with already long ago, only we went there to give a signature. People must eat the grass. The only right things have been stated by Ansip \& co. (juured, October 10th, 2012)

- If a thing is "ansipal" (of principle) or similar, then there's no need to eat seeds and wear a tinfoil hat. (ozbot, October 11th, 2012)

21 Compared to such a number of results in 2012 at the peak of the events, there has been an interesting slight increase in occurrences in recent years, as the count of 3,470 items demonstrates.

22 The term used by Mikhail Alekseevsky (2012) is remarkable in many aspects, but especially considering the aspect of changed interaction of creators and viewers.

23 The forum of LHV, an Estonian financial group. See https://fp.lhv.ee/forum/invest/128726?locale=et (accessed August 30th, 2016). 
The prime minister's furious outburst led to demands for an apology or even impeachment. The blamed man himself later used the excuse that his words were taken out of context. That kind of self-justification is widespread among politicians. It would be easier to avoid such failed behavior using public relations advisers, but it seems that no one can stop spontaneous politicians. The following example represents an analogous case.

\section{ACTA, FACEBOOK, AND THE DEFENSE MINISTER}

Similarly to the previous case, the following example concerns a politician's answers to journalists. The occasion was a government press conference, and the speaker was the defense minister, Mart Laar. This case is also related to ACTA because the minister was asked to comment on the disappearance of ACTA-related posts on his Facebook wall. The obviously uncomfortable question caused the minister to give an ambiguous reply and articles with the following titles appeared:

- Mart Laar: ACTA kirjed kadusid, sest mul sai Facebooki ruum otsa 'Mart Laar: the ACTA posts disappeared because I ran out of space on Facebook ${ }^{24}$

- Mart Laar interneti tsenseerimisest: mina ei kustutanud, ruum sai otsa 'Mart Laar on internet censorship: I didn't delete, I ran out of space ${ }^{25}$

- Mart Laar kustutas oma Facebooki kontolt ACTAga seonduva arutelu 'Mart Laar deletes ACTA-related discussion from his Facebook wall ${ }^{26}$

- Laar: tegin Facebooki administraatoritele peapesu 'Laar: I berated the Facebook administrators ${ }^{27}$

The tabloid article was illustrated with a photo of the minister and the following caption:

THE INTERNET IS GROWING TOO SMALL: Defense Minister Mart Laar announced yesterday at a government press conference that his Facebook page was getting full. Therefore, posts commenting on ACTA, considered by many to be an uncomfortable topic for the government, were deleted. ${ }^{28}$

The minister's quote itself was used word-for-word in the news item:

${ }^{24}$ See http://www.delfi.ee/news/paevauudised/eesti/video-mart-laar-acta-kirjed-kadusid-sest-mul-saifacebooki-ruum-otsa.d?id=63831002 (accessed August 30th, 2016).

25 See http://www.ohtuleht.ee/461910 (accessed August 30th, 2016).

26 See http://majandus24.postimees.ee/v2/717050/mart-laar-kustutas-oma-facebooki-kontolt-actagaseonduva-arutelu (accessed August 30th, 2016).

27 See http://majandus24.postimees.ee/v2/717510/laar-tegin-facebooki-administraatoritele-peapesu (accessed August 30th, 2016).

28 See http://www.ohtuleht.ee/461910 (accessed August 30th, 2016). 
"I do not think I removed everything from there. What is going on there, the last time I saw it, is quite a functional dispute. If something has disappeared, then in relation to the fact that some time ago the space tended to fill up," explained Mart Laar in response to a query by a journalist from the [daily newspaper] Päevaleht as to why all comments about ACTA had been deleted from the minister's Facebook wall. Earlier, Laar had promised people that he would investigate ACTA and let people know how the Estonian government discusses it. ${ }^{29}$

This succinct, clumsy wording was enough to inspire numerous parodies. The people, including journalists, that started the avalanche first became angered by the minister breaking his initial promise: to be, as member of a minority party, "in the service of the people."

A new catchphrase emerged, which at first glance is not so much figurative as absurd: the internet/Facebook ran out of space or the internet has no more room for ACTA. However, the paradox underlying the sentence-the internet running out of available space-was enough for parodies to be created. Memes ${ }^{30}$ of the minister spread through the internet like wildfire.

Here is a selection of catchphrases in the demotivators ${ }^{31}$ that appeared on Facebook about the defense minister:

- ACTA on vajalik, et ruum otsa ei saaks 'ACTA is necessary so that space won't run out'

- Mina pole kustutanud, adminnid kustutasid'I haven't deleted, the admins deleted'

- Kui on kadunud, siis ruum kippus otsa saama 'If it's disappeared, then you tended to run out of space'

- Suur mees vajab palju ruumi 'A big man needs lots of space'

- Kui sein saab täis, siis kustutan ära. 'When my wall gets full, I will delete it' (Figure 9).

- Lópetage suurte tähtedega kirjutamine, facebook saab niimood täis ju 'Stop writing in caps lock. Facebook will get filled up that way' (Figure 10).

- Kim Yong Il kirjutas ülikooli ajal 1500 raamatut, Mart Laar täitis hommikuga terve Facebooki 'Kim Yong Il (sic) wrote 1500 books while in university. Mart Laar filled the whole Facebook in one morning' (Figure 11).

29 See http://www.ohtuleht.ee/461910 (accessed August 30th, 2016).

30 The definition of a meme in the context of the internet is described by Wikipedia as "some ideas, images, or carriers of cultural information, which via imitation spread on the internet like viruses." In addition to a broader meaning, there is more widespread use of it in a narrower sense. For more details, see also Shifman (2013) and Baran (forthcoming).

31 All of these mocking pictures were also published by the daily newspaper Postimees immediately after the minister's press conference interview. See http://www.postimees.ee/718622/veeb-taitub-martlaari-meemidega/ (accessed August 30th, 2016). 
The last one is a marvelous example of interaction of local and global, which is characteristic of internet culture. As Dorota Brzozowska and Liisi Laineste point out, "the emergence of local political motifs in the otherwise more global narratives shows that globalization and localization are indeed active processes and are equally relevant in shaping and constructing cultural texts" (2014: 380-381).

By combining what are at first glance incompatible motifs, ideas, figures, and so on, internet users conflate small communities' larger issues and eliminate the borders between these two types in that way.

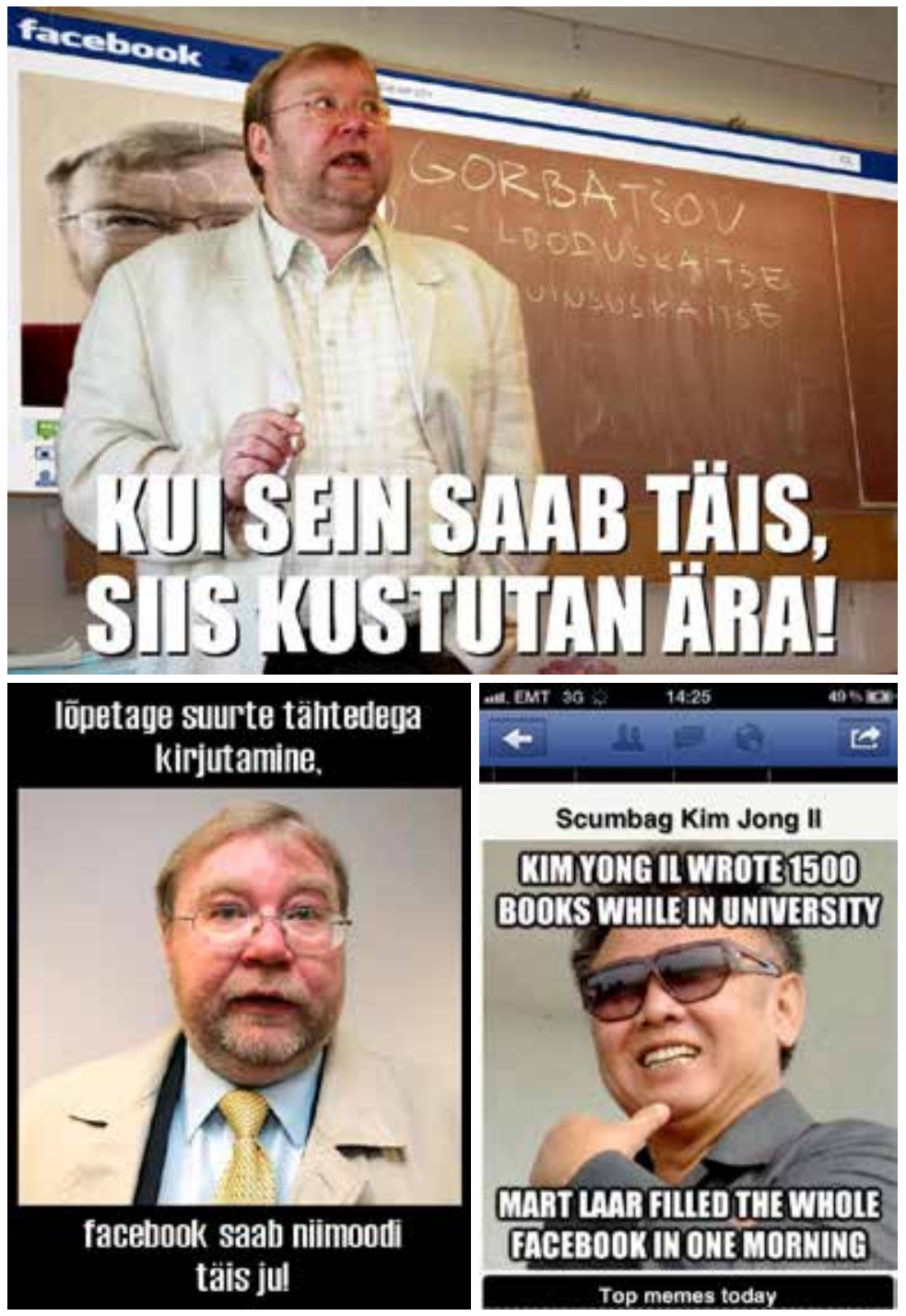

Figure 9, 10 and 11 
There was also a parody picture (see Figure 12) depicting an exchange between the defense minister and the aforementioned prime minister, combining, in that way, these two topics: Laar kuule, seemneid tahad osta? Jube hea kraam. - Sorry, pole ruumi. 'Laar, listen, wanna buy seeds? - Sorry, out of space.'

Similar to the case with the prime minister, people's reaction online quickly became playful. Thus, for example, an internet community was created with the name "Mart Laar's space," ${ }^{32}$ subtitled "A bit of space for Mart Laar where he can peacefully write without running out of space" as an explanation of the additional space by the community's creators.

Another parody of the series

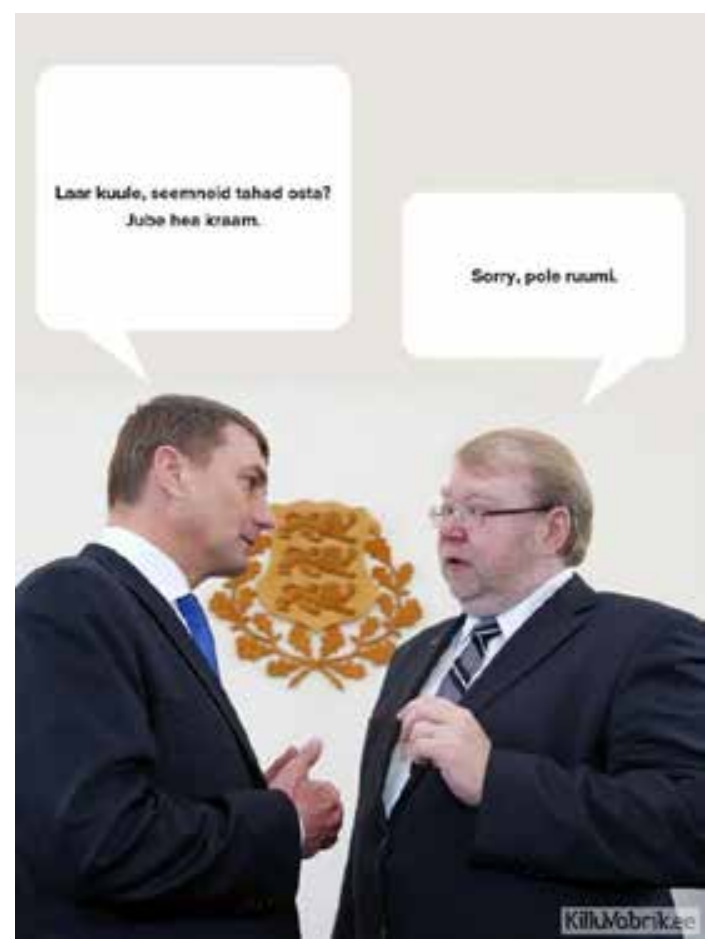

Figure 12. Parody picture "Hitler is angry again" was also posted to YouTube - Hitler saab teada, et Laaril sai ruum täis 'Hitler finds out that Laar has run out of space. ${ }^{33}$

\section{CONCLUSION}

I have found an apt anonymous comment that elegantly sums up both cases:

In principle, many politicians have ruined their image in the eyes of the people by showing how little they actually understand the internet. First Mart Laar's "ran out of internet" comment, and now Ansip's clanger yesterday. There are more politicians like this, but these are the biggest ones. ${ }^{34}$

32 See https://www.facebook.com/laariruum (accessed August 30th, 2016).

33 See http://www.youtube.com/watch?v=JFsz1df7030\&feature=youtube (accessed August 30th, 2016).

34 See http://www.delfi.ee/news/paevauudised/eesti/ansip-iroonitseb-pollumajandusega-on-nuud-labilaar-uritas-ei-saanud-hakkama-acta-teeb-selle-ara.d?id=63894023\&com=1\&no=160 (accessed August 30th, 2016). 
Researchers are increasingly dealing with internet studies, including internet language. Figurative language use is no longer, nor has it ever actually been, a thing in itself. There are various aspects that are equally important: linguistic, communicative-pragmatic, sociological, semiotic, and so on. Characteristic for contemporary internet society, some phenomena (e.g., verbal faux pas) are not merely just repeated. In the wilderness of the internet, florid language usage abounds, resulting in diversified variability. For a linguist, the phenomenon is interesting primarily as an example of living figurative (more or less expressive) language creation, taking place not in oral communication but written internet communication. As everyone knows, today it is common practice to illustrate online news items with visual aids and multimedia. The use of visual aids is a dominating factor in the internet environment. Such overwhelmingly "parody humor" is a diverse phenomenon based on the "mix and match" principle. Moreover, although visual humor is considered generally more universal than verbal, to understand the content one still needs to know the context or have background knowledge.

However, although such unfortunate expressions of opinion cause a lively reaction in society, they do not have much influence on the politician's career. In Estonia, in particular, the influence seems to be temporary: charismatic leaders are forgiven, especially when politicians use the most common excuse; namely, "taken out of context." Expressive language use, which is not considered best practice in politics, does temporarily incite greater media and publicity interest, and the unfortunate phrases can (for a little while) show the politician in a negative light, but they paradoxically have no impact on election results (at least not yet). This allows the conclusion that the digital age has brought about a disappearance of limits and wider publication; these new phenomena just take some time to have an effect on the social environment. However, these are clearly excellent means for people to express their opinions, falling like an online avalanche, and are becoming increasingly difficult for politicians to ignore. Such a relationship between the social and technological spheres is a new reality and everyone, including researchers, simply has to take it into account more often. 


\section{REFERENCES}

Alekseevsky, Mikhail. 2012. Who Are All Those People (the Ones with Placards)? Antropologicheskii Forum / Forum for Anthropology and Culture 7: 1-19. Available at http://anthropologie.kunstkamera.ru/ files/pdf/eng007/alekseevsky.pdf, accessed July 14, 2014.

Baran, Anneli. 2011. On the Role of Phraseologisms in the Estonian Online Media. In: Alicja Witalisz (ed.), Papers on Language, Culture and Literature 3. Prace naukowo-dydaktyczne/państwowej wyższej szkoty zawodowej w krośnie 55: 105-114. Krosno: Państwowa Wyższa Szkoła Zawodowa w Krośnie.

Baran, Anneli. 2012. Visual Humour on the Internet. In: Liisi Laineste, Dorota Brzozowska, \& Władysław Chłopicki (eds.), Estonia and Poland. Creativity and Tradition in Cultural Communication. Volume 1: Jokes and their Relations, pp. 171-186. Tartu: ELM Scholarly Press. Available at http://www.folklore.ee/pubte/eraamat/eestipoola/baran.pdf, accessed August 30th, 2016. doi:10.7592/EP.1.baran

Baran, Anneli. (forthcoming). Internet Creativeness: From Individuation to Social Force. In: Pekka Hakamies \& Anne Heimo (eds.), FF Communications 310. Helsinki: Academia Scientiarum Fennica.

Brzozowska, Dorota, \& Liisi Laineste. 2014. End of the World Narratives in Poland and Estonia: Images, Texts and Underlying Attitudes. In: Anneli Baran, Liisi Laineste, \& Piret Voolaid (eds.), Scala Naturae. Festschrift in Honour of Arvo Krikmann, pp. 357-388. Tartu: ELM Scholarly Press.

Laineste, Liisi. 2012. Verbal Expressions of Aggressiveness on the Estonian Internet. In: Liisi Laineste, Dorota Brzozowska, \& Władysław Chłopicki (eds.), Estonia and Poland. Creativity and Tradition in Cultural Communication. Volume 1: Jokes and Their Relations, pp. 171-186. Tartu: ELM Scholarly Press. Available at http://www.folklore.ee/pubte/eraamat/eestipoola/baran.pdf, accessed August 30th 2016. doi:10.7592/EP.1.laineste.liisi

Madisson, Mari-Liis. 2016. The Semiotic Construction of Identities in Hypermedia Environments: The Analysis of Online Communication of the Estonian Extreme Right. Dissertationes Semioticae Universitatis Tartuensis 23. Tartu: University of Tartu, Faculty of Philosophy, Institute of Philosophy and Semiotics, Department of Semiotics. Available at http://hdl.handle.net/10062/52174, accessed August 30th 2016.

Papacharizzi, A. Zizi. 2011. On Convergent Supersurfaces and Public Spheres Online. International Journal of Electronic Governance 4(1/2): 9-17. doi: http://dx.doi.org/10.1504/IJEG.2011.041704

Papacharizzi, A. Zizi, \& Maria de Fatima Oliveira. 2012. Affective News and Networked Publics: The Rhythms of News Storytelling on \#Egypt. Journal of Communication 62 (2): 266-282. doi: 10.1111/j.1460-2466.2012.01630.x

Shifman, Limor. 2012. An Anatomy of a YouTube Meme. New Media and Society 14: 187-203. doi: $10.1177 / 1461444811412160$

Shifman, Limor. 2013. Memes in Digital Culture. Cambridge, MA: MIT Press. 


\section{POLITIČNA RETORIKA IN OGLAŠEVANJE V DIGITALNI DOBI}

$V$ Estoniji je trgovinski sporazum za boj proti ponarejanju pritegnil večjo pozornost v januarju in februarju 2012. Novice o demonstracijah po vsem svetu so prav tako dosegle Estonijo. Socialna omrežja, kjer so bile oblikovane različne skupnosti, so pozivala ljudi, naj se zberejo in izrazijo svoje mnenje. Vendar so se protestniki pri rabi in repertoarju stališč večinoma zgledovali znanih estonskih politikih, ki so uporabili splet, da bi tudi na ta način labko posredovali svoja stališča in politicno lobirali.

Nekateri posamezniki svoje posebne ubesedovalne navade pri pisanju spletnih dnevnikov ali v družbena omrežja uporabljajo tudi pri drugih oblikah komunikacije z javnostjo. Pri tem jim pomagajo tudi mediji, ki čedalje bolj uporabljajo spletne dnevnike ali družbena omrežja in s tem ustvarijo novo, živahno diskusijo. Ti procesi pričajo o tem, da se v digitalni dobi zabrisujejo in izginjajo stare omejitve med javnim in zasebnim; rezultat so širši javnosti dostopna (samo)razkritja.

Dr. Anneli Baran, Department of Folkloristics, Estonian Literary Museum, 50003 Tartu, Estonia, anneli@folklore.ee 